Author affiliations appear at the end of this article.

Published online ahead of print at www.jco.org on October 3, 2016.

Supported in part by the Associazione Italiana Lotta alla Leucemia sezione di Bergamo, the Associazione Italiana per la Ricerca sul Cancro (Grants No. 9962 to A.R. and No. 10007 to S.P.), Ministero Istruzione, Università e Ricerca (Grant No. PRIN 2010), and unrestricted grants from Roche SpA and Amgen, Italy.

Presented in part at the 54th American Society of Hematology Annual Meeting, Atlanta, GA, December 8-11, 2012, and the 12th International Conference on Malignant Lymphoma, Lugano, Switzerland, June 19-22, 2013

Authors' disclosures of potential conflicts of interest are found in the article online at www.jco.org. Author contributions are found at the end of this article.

Clinical trial information: NCT00355199.

Corresponding author: Alessandro Rambaldi, MD, University of Milan, Hematology and Bone Marrow Transplant Unit, Ospedale Papa Giovanni XXIII, Piazza OMS, 1, 24127 Bergamo, Italy; e-mail: arambaldi@asst-pg23.it.

C 2016 by American Society of Clinical Oncology

0732-183X/16/3499-1/\$20.00

DOI: $10.1200 / J C 0.2016 .67 .2980$

\title{
Randomized Trial Comparing R-CHOP Versus High-Dose Sequential Chemotherapy in High-Risk Patients With Diffuse Large B-Cell Lymphomas
}

Sergio Cortelazzo, Corrado Tarella, Alessandro Massimo Gianni, Marco Ladetto, Anna Maria Barbui, Andrea Rossi, Giuseppe Gritti, Paolo Corradini, Massimo Di Nicola, Caterina Patti, Antonino Mulé, Manuela Zanni, Valerio Zoli, Atto Billio, Andrea Piccin, Giovanni Negri, Claudia Castellino,

Francesco Di Raimondo, Andrés J.M. Ferreri, Fabio Benedetti, Giorgio La Nasa, Guido Gini, Livio Trentin, Maurizio Frezzato, Leonardo Flenghi, Simona Falorio, Marco Chilosi, Riccardo Bruna, Valentina Tabanelli, Stefano Pileri, Arianna Masciulli, Federica Delaini, Cristina Boschini, and Alessandro Rambaldi

\section{$\begin{array}{llllllll}\text { A } & \text { B } & \text { S } & \text { T } & \text { R } & \text { A } & \text { C } & \text { T }\end{array}$}

\section{Purpose}

The benefit of high-dose chemotherapy with autologous stem-cell transplantation (ASCT) as first-line treatment in patients with diffuse large B-cell lymphomas is still a matter of debate. To address this point, we designed a randomized phase III trial to compare rituximab plus cyclophosphamide, doxorubicin, vincristine, and prednisone (R-CHOP)-14 (eight cycles) with rituximab plus high-dose sequential chemotherapy (R-HDS) with ASCT.

\section{Patients and Methods}

From June 2005 to June 2011, 246 high-risk patients with a high-intermediate (56\%) or high (44\%) International Prognostic Index score were randomly assigned to the R-CHOP or R-HDS arm, and 235 were analyzed by intent to treat. The primary efficacy end point of the study was 3-year event-free survival, and results were analyzed on an intent-to-treat basis.

\section{Results}

Clinical response (complete response, 78\% $v 76 \%$; partial response, 5\% $v$ 9\%) and failures (no response, 15\% v11\%; and early treatment-related mortality, $2 \% v 3 \%$ ) were similar after R-CHOP versus R-HDS, respectively. After a median follow-up of 5 years, the 3-year event-free survival was $62 \%$ versus $65 \%(P=.83)$. At 3 years, compared with the R-CHOP arm, the R-HDS arm had better disease-free survival (79\% v91\%, respectively; $P=.034)$, but this subsequently vanished because of late-occurring treatment-related deaths. No difference was detected in terms of progression-free survival $(65 \% \vee 75 \%$, respectively; $P=.12)$, or overall survival $(74 \% \vee 77 \%$, respectively; $P=.64)$. Significantly higher hematologic toxicity $(P<.001)$ and more infectious complications $(P<.001)$ were observed in the R-HDS arm.

\section{Conclusion}

In this study, front-line intensive R-HDS chemotherapy with ASCT did not improve the outcome of high-risk patients with diffuse large B-cell lymphomas.

\section{J Clin Oncol 34. (C) 2016 by American Society of Clinical Oncology}

\section{INTRODUCTION}

Diffuse large B-cell lymphoma (DLBCL) is an aggressive, but potentially curable, malignancy accounting for approximately $30 \%$ to $35 \%$ of all newly diagnosed B-cell lymphomas. ${ }^{1}$ The outcome of the disease is heterogeneous and can be predicted by validated prognostic scores. ${ }^{2-4}$ In young patients with a good prognosis according to the International Prognostic Index (IPI), the long-term cure rate after rituximab-containing conventional chemotherapy programs now exceeds $80 \% .^{5}$ Long-term results for patients belonging to high-risk and high-intermediaterisk groups have also been improved by similar chemoimmunotherapy programs, but still remain unsatisfactory. ${ }^{6,7}$ In the prerituximab era, highdose (HD) chemotherapy programs followed by autologous stem-cell transplantation (ASCT) have been proposed as a way to improve the outcome of high-risk patients with $\mathrm{DLBCL}^{8-11}$; 
however, conflicting results have been reported. ${ }^{12-15}$ Three metaanalyses have been published, and none found clear evidence for the use of HD therapy. ${ }^{16-18}$ The addition of the anti-CD20 antibody rituximab and $\mathrm{HD}$ cytarabine (HD-Ara-C) to the original $\mathrm{HD}$ sequential schedule ${ }^{8}$ was reported as an innovative program for patients with mantle cell lymphoma and bone marrow involvement. ${ }^{19}$ This rituximab-based HD sequential therapy (R-HDS) was further developed and proved feasible and active in a multicenter phase II study in untreated patients with DLBCL with a high age-adjusted IPI (aaIPI) score. ${ }^{20}$ Similar results have been obtained in another phase II study with intensive immunochemotherapeutic protocols and ASCT. ${ }^{21}$

The study group Gruppo Italiano Terapie Innovative Linfomi launched a phase III trial to compare this R-HDS program with rituximab plus cyclophosphamide, doxorubicin, vincristine, and prednisone (R-CHOP) in adult patients with DLBCL with high and high-intermediate risk according to IPI.

\section{PATIENTS AND METHODS}

\section{Study Design and Procedures}

This open-label, multicenter, randomized phase III trial was sponsored by the Ospedale Papa Giovanni XXIII of Bergamo. The study was conducted in accordance with the International Conference on Harmonization for Good Clinical Practice guidelines and the Declaration of Helsinki, and was approved by the local ethical committees. Written informed consent was obtained before enrollment. The trial is registered at www.clinicaltrials.gov as NCT00355199.

\section{Patients}

Inclusion criteria were age of 18 to 65 years, biopsy-confirmed CD20positive DLBCL according to the 2008 WHO criteria, ${ }^{22}$ advanced Ann Arbor stage (stage III to IV or II with bulk defined as $\geq 10 \mathrm{~cm}$ or B symptoms) without CNS involvement, and no previous treatment. All patients from 18 to 60 years of age were in an aaIPI high-intermediate or high-risk group (aaIPI: two and three risk factors, respectively), as were those 61 to 65 years of age (IPI: 3 and 4 to 5 risk factors, respectively). Exclusion criteria were concurrent severe heart, kidney, lung, or liver disease or a positive serology for hepatitis B, hepatitis C, or HIV. Eligible patients were stratified by aaIPI or IPI, using the biased coin algorithm to ensure that the balance of patients' characteristics were within the randomization strata. Randomization was centralized at Mario Negri Sud Research Foundation through a Web-based system. A retrospective central pathology review was performed to determine the cell of origin ${ }^{23-25}$ by immunohistochemistry criteria. $^{26}$

\section{Treatment Plan}

Patients enrolled in the control arm received R-CHOP (rituximab $375 \mathrm{mg} / \mathrm{m}^{2}$ intravenously [IV], cyclophosphamide $750 \mathrm{mg} / \mathrm{m}^{2} \mathrm{IV}$, doxorubicin $50 \mathrm{mg} / \mathrm{m}^{2} \mathrm{IV}$, vincristine $1.4 \mathrm{mg} / \mathrm{m}^{2}$ IV given on day 1 and $100 \mathrm{mg} / \mathrm{d}$ oral prednisone given on days 1 to 5), given every 14 days for eight cycles. The neutropenic phase was supported by granulocyte colony-stimulating factor (filgrastrim $5 \mu \mathrm{g} / \mathrm{kg}$ subcutaneously given daily or pegfilgrastim subcutaneously given once on day 1 of each cycle). CNS prophylaxis with intrathecal chemotherapy (methotrexate, Ara-C, corticosteroids) was given to high-risk patients who, at diagnosis, had infiltration of the bone marrow, testes, Waldeyer ring, cranial air sinuses (including nasal), salivary glands, and epidural space. In the R-CHOP group, 33 patients $(27 \%)$ received intrathecal prophylaxis. The experimental arm (R-HDS $)^{20}$ was based on three initial courses of doxorubicin-containing chemotherapy (first doxorubicin administration at $50 \mathrm{mg} / \mathrm{m}^{2} \mathrm{IV}$, then the full dose of
$75 \mathrm{mg} / \mathrm{m}^{2} \mathrm{IV}$ at 14 and 28 days; vincristine $1.4 \mathrm{mg} / \mathrm{m}^{2}$ IV on days 1,14 , and 28; oral prednisone $40 \mathrm{mg} / \mathrm{m}^{2}$ on days 1 to 28 ). Subsequently, patients received (1) HD cyclophosphamide $7 \mathrm{~g} / \mathrm{m}^{2}$ IV (day 1) and rituximab $375 \mathrm{mg} / \mathrm{m}^{2}$ IV (days 3 and 11), followed by the harvest of peripheral blood progenitor cells (PBPCs); (2) HD-Ara-C $2 \mathrm{~g} / \mathrm{m}^{2} \mathrm{IV}$ (twice a day for 6 days), followed on day 7 by the infusion of 1.5 to $2 \times 10^{6}$ autologous CD $34+$ cells $/ \mathrm{kg}$ and rituximab $375 \mathrm{mg} / \mathrm{m}^{2}$ IV (day 8 and day 16); a second PBPC harvest was scheduled after HD-Ara-C if inadequate harvesting was obtained after HD-cyclophosphamide or in the case of initial bone marrow involvement; (3) HD etoposide $2.4 \mathrm{~g} / \mathrm{m}^{2}$ IV (day 1), cisplatin $100 \mathrm{mg} / \mathrm{m}^{2}$ IV (day 2); a small amount of PBPC $\left(2 \times 10^{6} \mathrm{CD} 34+\right.$ cells $\left./ \mathrm{kg}\right)$ were reinfused following etoposide/cisplatin. The final ASCT was conditioned with mitoxantrone $\left(60 \mathrm{mg} / \mathrm{m}^{2} \mathrm{IV}\right)$ on day -5 and melphalan $\left(180 \mathrm{mg} / \mathrm{m}^{2} \mathrm{IV}\right)$ on day -2 or carmustine, etoposide, cytarabine, and melphalan (carmustine $300 \mathrm{mg} / \mathrm{m}^{2} \mathrm{IV}$ on day -6 , etoposide $200 \mathrm{mg} / \mathrm{m}^{2}$ IV on days -5 to -2 , Ara-C $200 \mathrm{mg} / \mathrm{m}^{2}$ IV every $12 \mathrm{~h} \times$ eight doses on days -5 to -2 , melphalan $140 \mathrm{mg} / \mathrm{m}^{2} \mathrm{IV}$ on day -1 ), and supported by PBPC autograft on day 0 . The target harvest for ASCT was $5 \times 10^{6} \mathrm{CD} 34+$ cells $/ \mathrm{kg}$. Two additional rituximab doses were scheduled on days 14 and 24 after ASCT. In both arms, patients with initial bulky ( $\geq 5 \mathrm{~cm}$ ) or residual lesions received involvedfield radiotherapy within 2 to 3 months after the chemotherapy program (Appendix Fig A1, online only). Patients received antiprophylaxis with sulfamethoxazole/trimethoprim and acyclovir prophylaxis for Pneumocystis jiroveci and herpes virus.

\section{Evaluation of Response and Toxicity}

After four cycles, patients assigned to R-CHOP underwent a first response evaluation (on the basis of a computed tomography scan and bone marrow biopsy, when indicated). Patients who achieved at least a partial response (PR) were given four additional courses; patients with less than a PR or refractory disease were shifted to salvage treatment. Clinical response was assessed by complete restaging according to Cheson criteria, ${ }^{27,28}$ including total-body positron emission tomography (PET). Residual computed tomography and $\left[{ }^{18} \mathrm{~F}\right]$ fluorodeoxyglucose-PETpositive masses should be biopsied whenever possible. In the absence of a confirmed positive biopsy, isolated $\left[{ }^{18} \mathrm{~F}\right]$ fluorodeoxyglucose-PET positivity was not considered an event. Adverse events were graded according to the National Cancer Institute Common Terminology Criteria for Adverse Events (version 3).

\section{Statistical Analysis}

The primary end point of the study was event-free survival (EFS), measured from the time of study entry to any treatment failure, including death, disease progression, or treatment discontinuation for any reason (eg, toxicity and patient or medical decision). This composite end point was chosen for its value in evaluating highly toxic therapies. ${ }^{28}$ The sample size of the study protocol was estimated to test a difference of $20 \%$ of the 3-year EFS rate between R-CHOP-14 and R-HDS. A sample of 224 patients randomly assigned to a treatment group (112 for each arm) over a period of 3 years, with 2 years of additional follow-up, was required for a power of 0.80 with a one-sided $\alpha$ level of .05 . We assumed a dropout rate of $10 \%$; we estimated that 240 patients would be needed to allocate 112 patients per arm.

According to Cheson guidelines, ${ }^{28}$ the secondary end points were response rate, progression-free survival (PFS), disease-free survival (DFS), overall survival (OS), ${ }^{29}$ and toxicity. Cox proportional hazards models were used to estimate the effects of the variables by univariable and multivariable setting. Proportional hazards assumption was verified for all models. Qualitative data were analyzed by the use of the $\chi^{2}$ test and, if appropriate, by Fisher's exact test. Statistical analyses were performed by $\mathrm{R}$ software (version 3.1.2; R Foundation for Statistical Computing, Vienna, Austria; https://www.R-project.org/) and SAS (version 9.3; SAS Institute, Cary, NC) software. All $P$ values are based on two-sided tests and considered significant when $<.05$. 


\section{RESULTS}

\section{Characteristics of Patients and Procedures}

From June 2005 to June 2011, 249 patients were assessed for eligibility (Fig 1). Of the 249 registered patients, three were excluded because of an unconfirmed diagnosis (follicular lymphoma, $\mathrm{n}=1)$, hepatitis $\mathrm{B}$ serology $(\mathrm{n}=1)$, and withdrawn consent before randomization $(n=1)$. Of the remaining 246 patients randomly assigned to R-CHOP $(\mathrm{n}=126)$ and R-HDS $(\mathrm{n}=120)$, the pathology review excluded seven patients who did not fulfil the histology criteria. One patient in the R-CHOP group (death before starting treatment) and five in the R-HDS group (death before starting treatment, $\mathrm{n}=1$; consent withdrawal, $\mathrm{n}=4$ ) did not receive the allocated treatment. The characteristics at enrollment of the 235 patients who formed the intention-to-treat-population are listed in Table 1. The two arms were well balanced with respect to all presenting features. Eight patients $(3.4 \%)$ had a residual low-grade histology. The median age was 51 years (range, 19 to 66 years), with 26 patients $(11 \%)>60$ years of age. Adverse clinical features were as follows: Ann Arbor stage III to IV (92\%), elevated lactate dehydrogenase level (85\%), Eastern Cooperative Oncology Group Performance Status $>1$ (62\%), $\geq 2$ extranodal sites (44\%), bone marrow infiltration (20\%), bulky disease (69\%), and B symptoms (59\%). Accordingly, the risk score evaluation by IPI was high-intermediate in $57 \%$ of patients and high in $43 \%$. No randomization imbalance was found according to the cell of origin evaluated retrospectively. The National Comprehensive Cancer Network-IPI ${ }^{4}$ was also retrospectively calculated, and $63 \%$ of patients had a risk score $>3$.

\section{Clinical Response}

A complete response (CR) or unconfirmed complete response $(\mathrm{CRu})$ was observed in 95 of 122 patients treated with R-CHOP (78\%) versus 86 of 113 patients treated with $\mathrm{R}-\mathrm{HDS}(76 \% ; P=.74)$, whereas a PR was documented in six of $122(5 \%)$ and 10 of $113(9 \%)$ patients, respectively $(P=.23)$. Accordingly, the overall response rate was $83 \%$ versus $85 \%(P=.65)$. Progressive disease was observed in 19 of 122 patients (15\%) in the R-CHOP arm and 12 of 113 patients $(10 \%)$ in the R-HDS arm $(P=.36)$, with only one patient with stable disease in the R-HDS arm; these were considered primary refractory patients. One patient in the R-HDS group was not evaluable (Table 2). In the R-CHOP and R-HDS groups, the treatment was discontinued in six patients $(5 \%)$ versus 22 patients $(19 \%)$, respectively $(P<.001)$, because of infections (one $v$ six), other toxicities (hematologic, one $v$ six; cardiovascular, one $v$ three; other, one $v$ two; medical, one $v$ two), or patient decision (one $v$ three). The final autograft was performed in 80 of 113 patients $(71 \%)$ in the R-HDS group, with a median of $7.2 \times 10^{6} / \mathrm{kg} \mathrm{CD} 34+$ cells (range, 3 to $30 \times 10^{6} / \mathrm{kg}$ ). No graft failures were reported. Radiotherapy was performed in 37 of 122 patients $(30 \%)$ in the R-CHOP group and 16 of 113 patients $(14 \%)$ in the R-HDS group $(P=.003)$.

\section{Clinical Outcomes}

In the R-CHOP group, 73 of the 95 patients who had achieved $\mathrm{CR} / \mathrm{CRu}$ remained alive and in continuous CR (73 of 122 patients; $60 \%$ ), seven died in CR, and 15 relapsed (12 patients died and three are alive after achievement of a second CR). In the R-HDS group, of the 86 patients who had achieved CR/CRu, 74 remained alive in continuous CR (74 of 113; 65\%), six died in CR, and six experienced relapse (four later died, two are still alive). Of the six

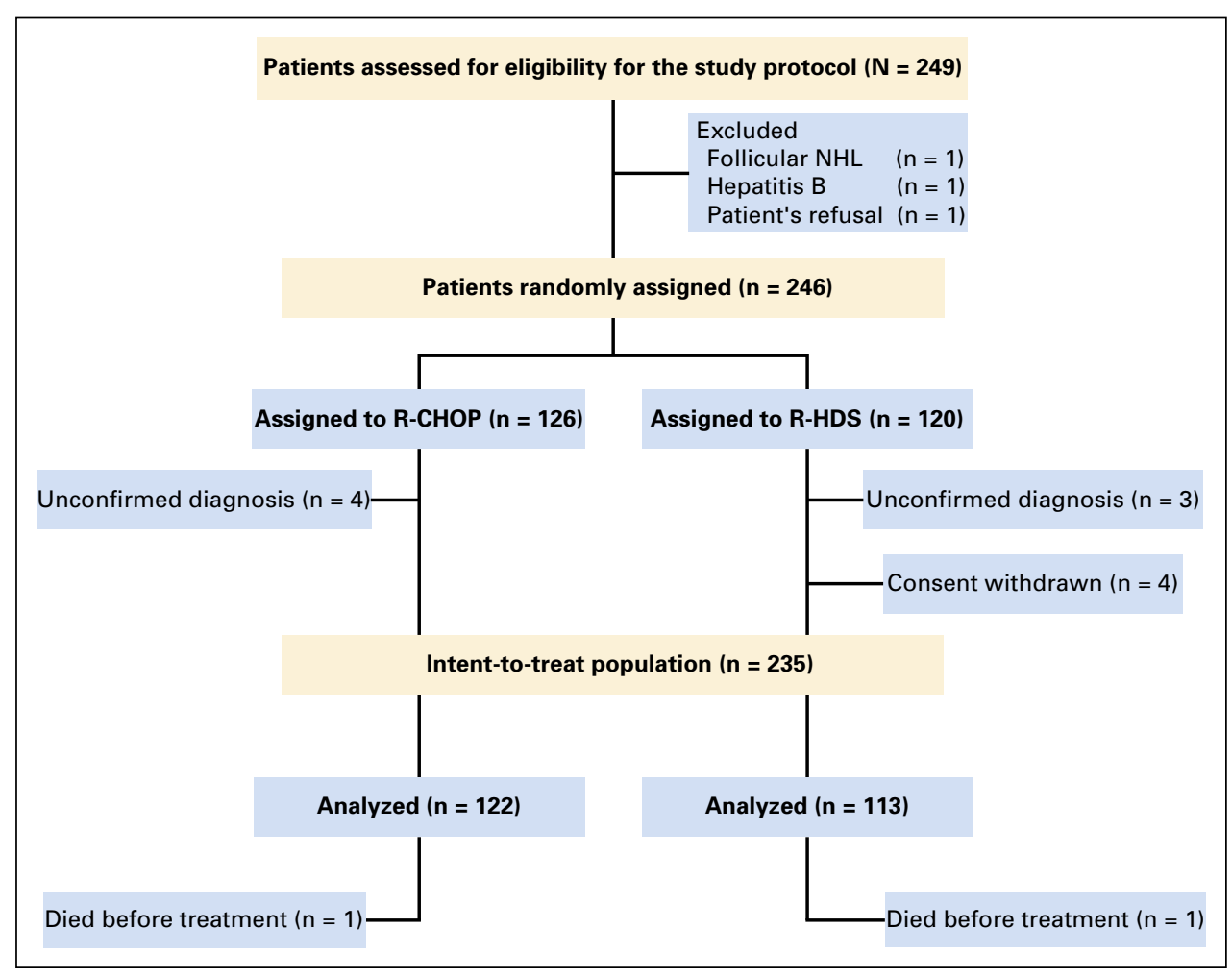

Fig 1. CONSORT diagram of the study. $\mathrm{NHL}$, non-Hodgkin lymphoma; R-CHOP, rituximab plus cyclophosphamide, doxorubicin, vincristine, and prednisone; R-HDS, rituximab plus high-dose sequential chemotherapy. 


\begin{tabular}{|c|c|c|c|c|}
\hline Characteristic & $\begin{array}{l}\text { All Patients, } \\
\text { No. (\%) } \\
(\mathrm{N}=235)\end{array}$ & $\begin{array}{l}\text { R-CHOP, } \\
\text { No. (\%) } \\
(n=122)\end{array}$ & $\begin{array}{c}\text { R-HDS } \\
\text { No. }(\%) \\
(\mathrm{n}=113)\end{array}$ & $P$ \\
\hline \multicolumn{5}{|l|}{ Age, years } \\
\hline Median (range) & $51(19-66)$ & $49(19-66)$ & $53(19-65)$ & .44 \\
\hline$\leq 60$ & 209 (89) & $108(89)$ & 101 (89) & .83 \\
\hline$>60$ & $26(11)$ & $14(11)$ & $12(11)$ & \\
\hline \multicolumn{5}{|l|}{ Sex } \\
\hline Male & $136(58)$ & $71(58)$ & $65(58)$ & .92 \\
\hline Female & $99(42)$ & $51(42)$ & $48(42)$ & \\
\hline \multicolumn{5}{|l|}{ ECOG performance status } \\
\hline 0 & $37(16)$ & $21(17)$ & $16(14)$ & .36 \\
\hline 1 & $53(23)$ & $25(20)$ & $28(25)$ & \\
\hline 2 & $117(50)$ & $65(53)$ & $52(46)$ & \\
\hline 3 & $28(12)$ & $11(9)$ & $17(15)$ & \\
\hline \multicolumn{5}{|l|}{ Ann Arbor clinical stage } \\
\hline ॥ & $19(8)$ & $9(7)$ & $10(9)$ & .91 \\
\hline III & $54(23)$ & $28(23)$ & $26(23)$ & \\
\hline IV & $162(69)$ & $85(70)$ & 77 (68) & \\
\hline \multicolumn{5}{|l|}{ Bulky disease* } \\
\hline No & $72(31)$ & $37(30)$ & $35(31)$ & .88 \\
\hline Yes & $162(69)$ & $85(70)$ & 77 (68) & \\
\hline \multicolumn{5}{|l|}{ B symptoms* } \\
\hline No & $93(40)$ & $51(42)$ & $42(37)$ & .54 \\
\hline Yes & $138(59)$ & $70(57)$ & $68(60)$ & \\
\hline \multicolumn{5}{|l|}{ Bone marrow infiltration* } \\
\hline No & $177(75)$ & $93(76)$ & $84(74)$ & .86 \\
\hline Yes & $47(20)$ & $24(20)$ & $23(20)$ & \\
\hline \multicolumn{5}{|l|}{ No. of extranodal sites } \\
\hline $0-1$ & $132(56)$ & $70(57)$ & $62(55)$ & .70 \\
\hline$\geq 2$ & $103(44)$ & $52(43)$ & $51(45)$ & \\
\hline \multicolumn{5}{|l|}{ Elevated LDH (ratio to ULN) } \\
\hline$\leq 1$ & $34(14)$ & $17(14)$ & $17(15)$ & .93 \\
\hline$>1-\leq 3$ & $165(70)$ & $87(71)$ & $78(69)$ & \\
\hline$>3$ & $36(15)$ & $18(15)$ & $18(16)$ & \\
\hline \multicolumn{5}{|l|}{ IPIt } \\
\hline High-intermediate risk & $133(57)$ & $67(55)$ & $66(58)$ & .59 \\
\hline High risk & $102(43)$ & $55(45)$ & $47(42)$ & \\
\hline \multicolumn{5}{|l|}{ NCCN IPI } \\
\hline$\leq 3$ & 87 (37) & $45(37)$ & 42 (37) & .96 \\
\hline$>3$ & $148(63)$ & $77(63)$ & 71 (63) & \\
\hline \multicolumn{5}{|l|}{ Cell of origin } \\
\hline Non-GCB & $112(48)$ & $54(44)$ & $58(51)$ & .68 \\
\hline $\mathrm{GCB}$ & $64(27)$ & $35(29)$ & $29(26)$ & \\
\hline PML & 27 (11) & $14(11)$ & $13(12)$ & \\
\hline $\mathrm{NE}$ & $32(14)$ & $19(16)$ & $13(12)$ & \\
\hline \multicolumn{5}{|c|}{$\begin{array}{l}\text { Abbreviations: ECOG, Eastern Cooperative Oncology Group; GCB, germinal } \\
\text { center B-cell-like; IPI, International Prognostic Index; LDH, lactate de- } \\
\text { hydrogenase; NCCN, National Comprehensive Cancer Network; NE, not } \\
\text { evaluable for lack of material; PML, primary mediastinal lymphoma; R-CHOP, } \\
\text { rituximab plus cyclophosphamide, doxorubicin, vincristine, and prednisone; } \\
\text { R-HDS, rituximab plus high-dose sequential chemotherapy; UNL, upper limit } \\
\text { of normal range. } \\
\text { *One missing datum in the R-HDS arm for bulky disease; three missing data for } \\
\text { B symptoms in the R-HDS arm and one in the R-CHOP arm; six and five missing } \\
\text { data for bone marrow in the R-HDS arm and in the R-CHOP arm, respectively. } \\
\text { tHigh-intermediate: age-adjusted IPI = 2, IPI = 3; high risk: age-adjusted IPI = 3, } \\
\text { IPI = 4-5. }\end{array}$} \\
\hline
\end{tabular}

patients who achieved a partial remission after R-CHOP, three remained alive, two experienced disease progression (one died and one is alive in second CR), and one was lost to follow-up. Of the 10 patients treated with R-HDS who were judged as partial remitters, three are alive without additional treatment, five experienced disease progression (three died and two are in CR following additional treatment), one died of a secondary cancer, and one died of treatment-related toxicity. A CNS progression/relapse occurred in

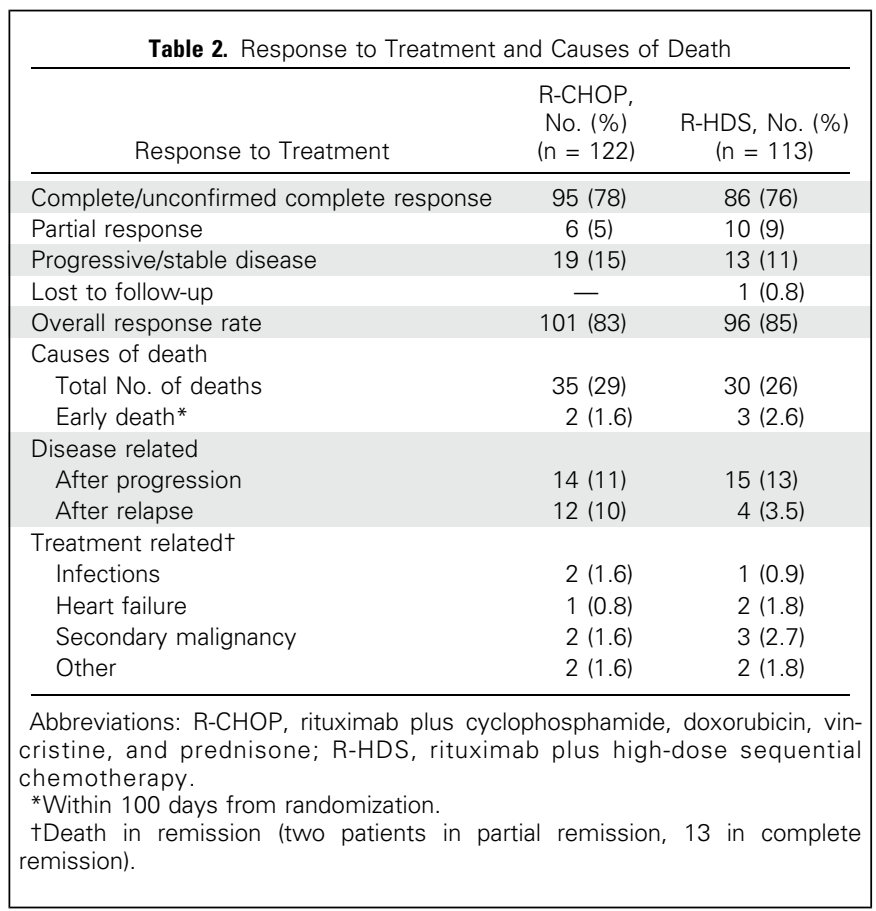

seven of 122 patients (5.7\%) in the R-CHOP arm and five of 113 $(4.4 \%)$ in the R-HDS arm $(P=.65)$. Of the 19 patients who had progressive disease after R-CHOP, 13 died and six are alive. All 12 patients with progressive disease after receiving R-HDS died. The patient with stable disease was lost to follow-up.

After a median follow-up of 5 years (range, 0.05 to 9.49), by an intent-to-treat analysis, the 3-year EFS was 62\% (95\% CI, 54\% to $71 \%$ ) for patients treated with R-CHOP versus $65 \%$ (95\% CI, 56\% to $74 \%$ ) for patients treated with R-HDS ( $P=.83$; hazard ratio, $0.99 ; 95 \%$ CI, 0.66 to 1.48 ; Fig $2 \mathrm{~A}$ ). The same lack of difference was observed when data were analyzed within the IPI subgroups (Figs $2 \mathrm{~B}$ and $2 \mathrm{C}$ ). Similarly, treatments did not significantly affect the 3 -year PFS, which was 65\% in the R-CHOP arm (95\% CI, 57\% to $74 \%$ ) versus $75 \%(95 \% \mathrm{CI}, 67 \%$ to $83 \%$; $\mathrm{P}=.119)$ after $\mathrm{R}-\mathrm{HDS}$ in the whole population (Fig 2D), as well as within IPI subgroups (Figs 2E and 2F). Interestingly, the 3-year DFS was better in the experimental arm, at 79\% (95\% CI, 71\% to $87 \%$ ) versus $91 \%(95 \%$ CI, $85 \%$ to $97 \%$ ) in the R-CHOP and R-HDS arms, respectively $(P=.033)$, even though this difference was lost after a longer follow-up (Fig 3A). No difference was found in terms of OS, at 74\% (95\% CI, 67\% to $82 \%$ ) in the R-CHOP arm versus $77 \%$ (95\% CI, $70 \%$ to $86 \%)$ in the R-HDS arm $(P=.64)$, no matter what the IPI risk subgroup was (Figs 3D, 3E, and $3 \mathrm{~F}$ ). Interestingly, the subgroup analysis describing the outcome of patients who did not discontinue the allocated treatment because of medical or patient decision or toxicity showed a significant benefit of the R-HDS program in terms of PFS and DFS, but not OS (Appendix Fig A2).

By univariable analysis, factors affecting age, performance status, and IPI subgroups showed a significant impact on EFS, PFS, and OS. Bulky disease was also significant on EFS (Appendix Table A1, online only). No evidence of differential benefit according to the cell of origin emerged from treatment intensification. By multivariable analysis, IPI remained the only factor significantly affecting the same outcomes (Appendix Table A2, online only). 


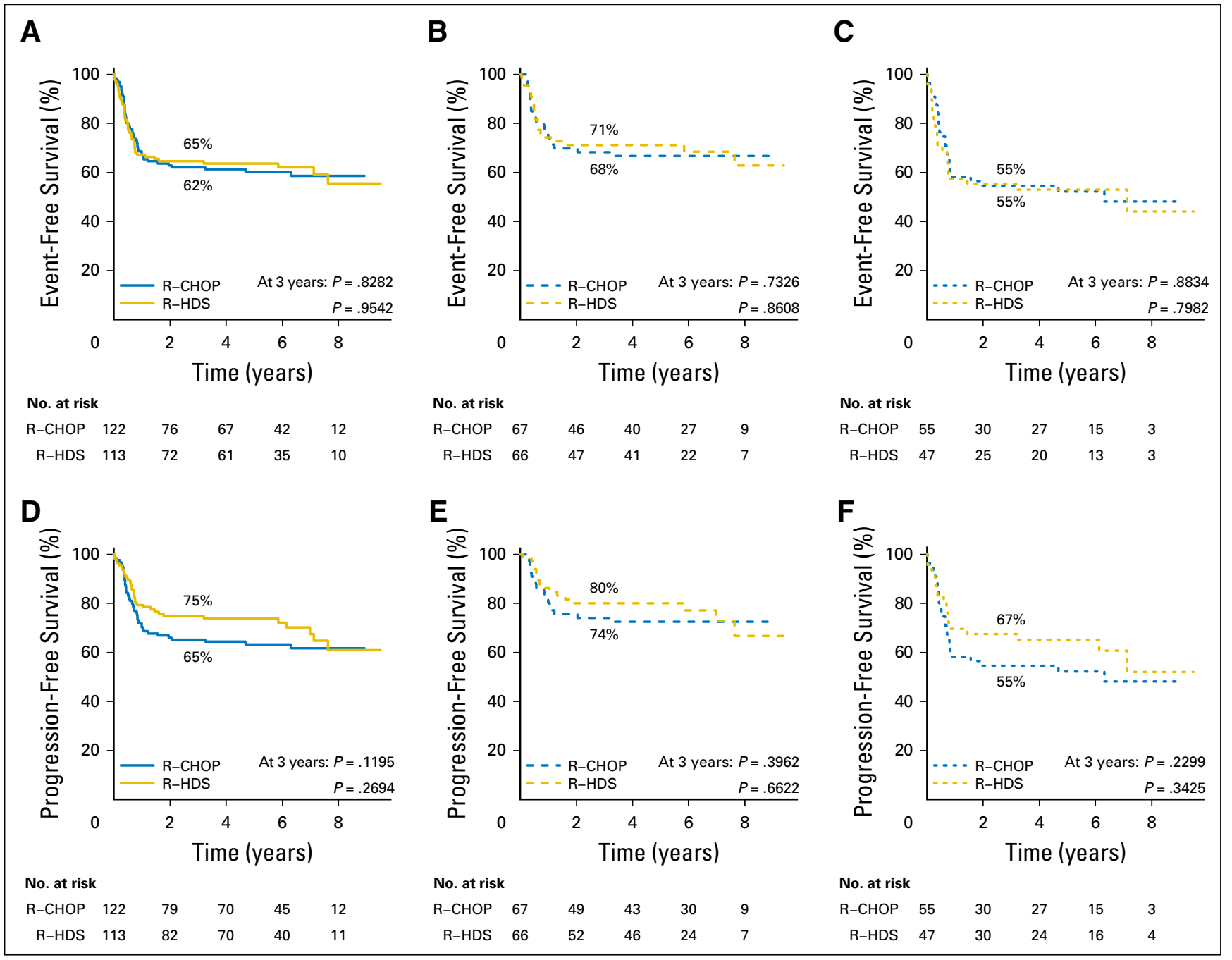

Fig 2. Event-free survival (EFS) and progression-free survival (PFS) curves according to treatment randomization. (A) EFS in all patients; (B) EFS in high-intermediate-risk patients; (C) EFS in high-risk patients; (D) PFS in all patients; (E) PFS in high-intermediate-risk patients; and (F) PFS in high-risk patients. EFS was measured from the time of study entry to any treatment failure, including disease progression, or discontinuation of treatment for any reason (eg, disease progression, toxicity, patient preference, initiation of new antilymphoma treatment, or death) or date of the last follow-up visit. PFS was defined as the time from study entry to disease progression or death as a result of any cause or date of the last follow-up visit. R-CHOP, rituximab plus cyclophosphamide, doxorubicin, vincristine, and prednisone; R-HDS, rituximab plus highdose sequential chemotherapy.

\section{Toxicity}

A lower rate of grade 3 to 4 hematologic toxicity was recorded in the R-CHOP arm compared with the R-HDS arm, with at least one episode of neutropenia in $34 \%$ versus $84 \%$ of patients $(P<.001)$, anemia in $15 \%$ versus $71 \%$ of patients $(P<.001)$, and thrombocytopenia in $5 \%$ versus $86 \%$ of patients $(P<.001$; Table 3). Patients receiving $\mathrm{R}-\mathrm{CHOP}$ had fewer episodes of mucositis, diarrhea, nausea, and vomiting $(11 \%$ v 29\%; $P<.001)$. A deeper neutropenia contributed to a higher frequency of severe infections in R-HDS patients $(54 \% v 8 \% ; P<.001)$. Sensory neurologic adverse effects were more frequent after R-CHOP $(7 \% \vee 0 \%)$, possibly as a consequence of the higher cumulative dose of vincristine received during treatment. A lower number of adverse events occurred in the R-CHOP arm versus the R-HDS arm ( $14 v$ $45 ; P<.001$ ), including those classified as serious (five $v 24$; $P<.001)$.

\section{Cause of Death}

Thirty-five patients $(29 \%)$ in the R-CHOP group and 30 $(26 \%)$ in the R-HDS group died. Two patients in the R-CHOP group and three in R-HDS group died within 100 days of diagnosis (early death). In the R-CHOP and R-HDS groups, 26 and 19 patients died as a result of disease, whereas seven and eight responding patients, respectively, died as a result of treatmentrelated toxicities (Table 2).

\section{DISCUSSION}

This randomized phase III trial demonstrates that the clinical outcome of patients with high-risk DLBCL treated with R-CHOP or an intensive R-HDS program is comparable. Both treatments provided similar results in terms of overall response rate and longterm outcomes. Therefore, the primary objective of this study to 
A

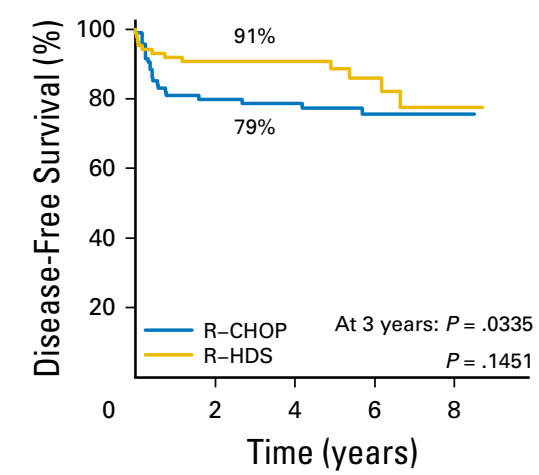

No. at risk

$\begin{array}{rrrrrr}\text { R-CHOP } & 95 & 75 & 63 & 35 & 7 \\ \text { R-HDS } & 86 & 77 & 54 & 24 & 4\end{array}$

D

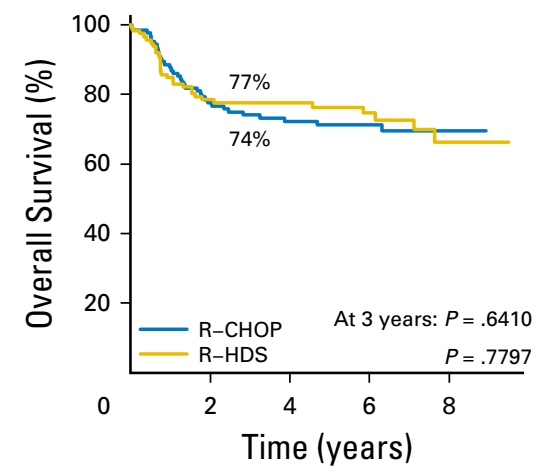

No. at risk

$\begin{array}{llllll}\text { R-CHOP } & 122 & 90 & 75 & 48 & 13\end{array}$

$\begin{array}{llllll}\text { R-HDS } & 113 & 86 & 73 & 41 & 13\end{array}$
B
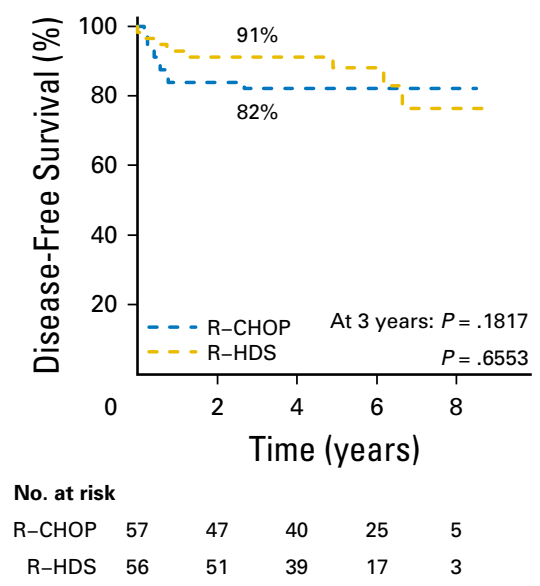

E

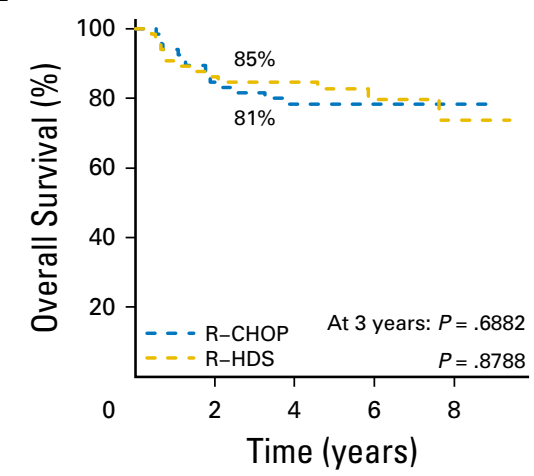

No. at risk

$\begin{array}{rrrrrr}\text { R-CHOP } & 67 & 54 & 46 & 33 & 10 \\ \text { R-HDS } & 66 & 56 & 48 & 24 & 8\end{array}$

C
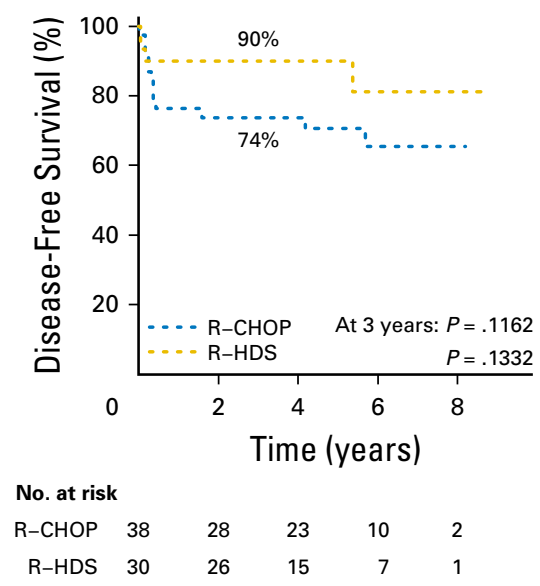

$\mathbf{F}$

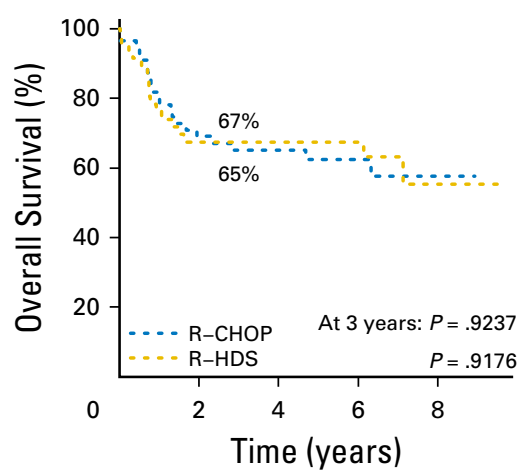

No. at risk

$\begin{array}{llllll}\mathrm{R}-\mathrm{CHOP} & 55 & 36 & 29 & 15 & 3\end{array}$

$\begin{array}{llllll}\text { R-HDS } & 47 & 30 & 25 & 17 & 5\end{array}$

Fig 3. Disease-free survival (DFS) and overall survival (OS) curves according to treatment randomization. (A) DFS in all patients; (B) DFS in high-intermediate-risk patients;

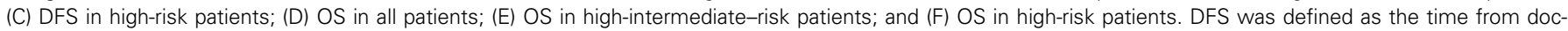

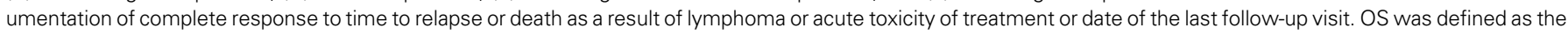

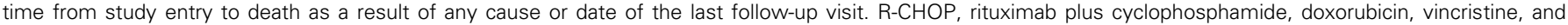
prednisone; R-HDS, rituximab plus high-dose sequential chemotherapy.

improve the EFS by the use of HD chemotherapy and ASCT was not achieved. Our study was conducted entirely in the rituximab era and was offered only to a homogeneous group of patients with DLBCL with unfavorable risk factors at diagnosis. Our results indicate that CHOP chemotherapy, optimally supplemented by eight doses of rituximab, ${ }^{30}$ remains the standard of care also for this group of patients at higher risk for disease resistance or recurrence. In a multicenter setting, R-HDS therapy had a higher rate of acute hematologic and infectious toxicities and was more difficult to complete when considering the higher rate of treatment discontinuation. The appropriate long-term follow-up allowed observation of better DFS at 3 years after R-HDS, although the robustness of the remission achieved after this intensive treatment vanished subsequently with the occurrence of late events.

When this study was designed, R-CHOP-14 treatment for eight cycles was selected as the control arm on the basis of the preliminary data of the German study group, which suggested an advantage of the dose-dense rituximab-based chemoimmunotherapy in elderly patients with DLBCL, ${ }^{31}$ and to avoid the possibility that a potential superior result of the intensive experimental arm could be attributable to a weaker conventional therapy. Nonetheless, the results of our study, which enrolled only high-risk (IPI 2 to 3) patients, are similar to those reported by using R-CHOP $(X$ six cycles every 14 days plus two cycles of rituximab or $X$ eight cycles every 21 days $)^{32}$ and comparable to those achieved when adopting an induction therapy also including etoposide. ${ }^{33}$

On the contrary, compared with standard R-CHOP, intensified immunochemotherapy with rituximab, doxorubicin, cyclophosphamide, vindesine, bleomycin, and prednisone significantly improved survival of low-risk patients, ${ }^{34}$ and this benefit was mostly observed in patients with non-germinal center B-cell (GCB) DLBCL. ${ }^{35}$ In our study, similar to the report on the phase II trial we previously published, ${ }^{20}$ the GCB versus non-GCB cell of origin did not predict a different outcome and was at variance with what was reported by the LNH03-2B study; we did not observe a better outcome among GCB patients treated with high-dose 


\begin{tabular}{|lccc|}
\hline \multicolumn{4}{|c|}{ Table 3. Grade III or IV Toxicity During Treatment } \\
\hline \multicolumn{1}{c}{ Toxicity } & $\begin{array}{c}\text { R-CHOP, No. * } \\
(\mathrm{n}=122)\end{array}$ & $\begin{array}{c}\text { R-HDS, No.* } \\
(\mathrm{n}=113)\end{array}$ & $P$ \\
\hline Neutropenia & $42(34)$ & $95(84)$ & $<.001$ \\
Anemia & $18(15)$ & $80(71)$ & $<.001$ \\
Thrombocytopenia & $6(5)$ & $97(86)$ & $<.001$ \\
Gl & $13(11)$ & $33(29)$ & $<.003$ \\
Cardiac & $9(7)$ & $5(4)$ & .34 \\
Neurologic & $9(7)$ & - & .0032 \\
Hepatic and metabolic & $7(6)$ & $8(7)$ & .67 \\
Infection & $10(8)$ & $61(54)$ & $<.001$ \\
\hline
\end{tabular}

Abbreviations: R-CHOP, rituximab plus cyclophosphamide, doxorubicin, vincristine, and prednisone; R-HDS, rituximab plus high-dose sequential chemotherapy.

*No. of patients with at least one reported episode of Common Terminology Criteria for Adverse Events (version 3) grade III or IV toxic events.

chemotherapy. However, in the French study, ${ }^{34}$ patients with only one aaIPI adverse factor were enrolled, which could explain better tolerance and results from the experimental treatment. Overall, the clinical value of a stratification on the basis of an immunostaining algorithm remains controversial with conflicting results. ${ }^{36,37}$ The lack of information about double- or triple-hit lymphomas remains a potential limitation of our study. ${ }^{38,39}$ The SWOG (Southwest Oncology Group)-9704 trial, which included different subtypes of B-cell and T-cell lymphomas, found that early consolidation with ASCT improved the PFS of patients with highintermediate risk or high risk who had a response to induction chemotherapy (2-year PFS, 69\% v 55\%) without any difference in OS between the two treatment arms. ${ }^{40}$ It is worth noting that the superiority of ASCT was limited to $35 \%$ of patients with high-risk IPI in whom either the PFS or OS was better than that of patients who received conventional chemotherapy, whereas in the prevailing group of patients with high-intermediate risk, there was no difference in terms of PFS and OS between the two treatment arms.
Preliminary results from another Italian study reported an advantage in terms of PFS but not OS in chemosensitive patients who proceeded to ASCT. ${ }^{41}$

In conclusion, this randomized trial indicates that both dosedense R-CHOP for eight cycles and R-HDS followed by autograft are equally effective in high-risk patients with DLBCL. Whether the addition of new drugs, such as lenalidomide ${ }^{42}$ and ibrutinib ${ }^{43}$ or monoclonal antibodies such as obinotuzumab, ${ }^{44}$ to R-CHOP therapy will be able to improve the outcome of high-risk patients with DLBCL is still under investigation.

\section{AUTHORS' DISCLOSURES OF POTENTIAL CONFLICTS OF INTEREST}

Disclosures provided by the authors are available with this article at www.jco.org.

\section{AUTHOR CONTRIBUTIONS}

Conception and design: Sergio Cortelazzo, Corrado Tarella, Alessandro Massimo Gianni, Marco Ladetto, Alessandro Rambaldi

Collection and assembly of data: Marco Ladetto, Anna Maria Barbui, Andrea Rossi, Giuseppe Gritti, Paolo Corradini, Massimo Di Nicola, Massimo Di Nicola, Caterina Patti, Antonino Mulé, Manuela Zanni, Valerio Zoli, Atto Billio, Andrea Piccin, Giovanni Negri, Claudia Castellino, Francesco Di Raimondo, Andrés J.M. Ferreri, Fabio Benedetti, Giorgio La Nasa, Guido Gini, Livio Trentin, Maurizio Frezzato, Leonardo Flenghi, Simona Falorio, Marco Chilosi, Riccardo Bruna, Valentina Tabanelli, Stefano Pileri, Arianna Masciulli, Federica Delaini Data analysis and interpretation: Sergio Cortelazzo, Corrado Tarella, Alessandro Massimo Gianni, Anna Maria Barbui, Arianna Masciulli, Cristina Boschini, Alessandro Rambaldi

Manuscript writing: All authors

Final approval of manuscript: All authors

Accountable for all aspects of the work: All authors

\section{REFERENCES}

1. Al-Hamadani M, Habermann TM, Cerhan JR, et al: Non-Hodgkin lymphoma subtype distribution, geodemographic patterns, and survival in the US: A longitudinal analysis of the National Cancer Data Base from 1998 to 2011. Am J Hematol 90:790-795, 2015

2. [No authors listed]: A predictive model for aggressive non-Hodgkin's lymphoma. The International Non-Hodgkin's Lymphoma Prognostic Factors Project. N Engl J Med 329:987-994, 1993

3. Sehn LH, Berry B, Chhanabhai M, et al: The revised International Prognostic Index (R-IPI) is a better predictor of outcome than the standard IPI for patients with diffuse large B-cell lymphoma treated with R-CHOP. Blood 109:1857-1861, 2007

4. Zhou Z, Sehn LH, Rademaker AW, et al: An enhanced International Prognostic Index (NCCN-IPI) for patients with diffuse large B-cell lymphoma treated in the rituximab era. Blood 123:837-842, 2014

5. Pfreundschuh $M$, Kuhnt $E$, Trümper $L$, et al: CHOP-like chemotherapy with or without rituximab in young patients with good-prognosis diffuse large-Bcell lymphoma: 6-year results of an open-label randomised study of the MabThera International Trial (MInT) Group. Lancet Oncol 12:1013-1022, 2011

6. Coiffier B, Thieblemont C, Van Den Neste E, et al: Long-term outcome of patients in the LNH-98.5 trial, the first randomized study comparing rituximabCHOP to standard CHOP chemotherapy in DLBCL patients: A study by the Groupe d'Etudes des Lymphomes de l'Adulte. Blood 116:2040-2045, 2010

7. Pfreundschuh $M$, Trümper $L$, Österborg $A$, et al: CHOP-like chemotherapy plus rituximab versus CHOP-like chemotherapy alone in young patients with good-prognosis diffuse large-B-cell lymphoma: A randomised controlled trial by the MabThera International Trial (MInT) Group. Lancet Oncol 7: 379-391, 2006

8. Gianni AM, Bregni M, Siena S, et al: High-dose chemotherapy and autologous bone marrow transplantation compared with MACOP-B in aggressive B-cell lymphoma. N Engl J Med 336:1290-1297, 1997

9. Cortelazzo S, Rossi A, Viero P, et al: BEAM chemotherapy and autologous haemopoietic progenitor cell transplantation as front-line therapy for high-risk patients with diffuse large cell lymphoma. Br J Haematol 99:379-385, 1997

10. van Imhoff GW, van der Holt $B$, Mackenzie $\mathrm{MA}$, et al: Impact of three courses of intensified $\mathrm{CHOP}$ prior to high-dose sequential therapy followed by autologous stem-cell transplantation as first-line treatment in poor-risk, aggressive non-Hodgkin's lymphoma: Comparative analysis of Dutch-Belgian Hemato-Oncology Cooperative Group Studies 27 and 40. J Clin Oncol 23:3793-3801, 2005

11. Gastinne T, Damaj G, Lamy $T$, et al: High-dose chemotherapy followed by autologous stem cell transplantation (auto-SCT) versus CHOP regimen in patients with untreated aggressive non-Hodgkin's lymphoma: An update of the GOELAMS 072 trial with a median follow-up of 9.8 years. Blood 112:770-781, 2008

12. Verdonck LF, van Putten $W L$, Hagenbeek $A$, et al: Comparison of CHOP chemotherapy with autologous bone marrow transplantation for slowly responding patients with aggressive non-Hodgkin's lymphoma. N Engl J Med 332:1045-1051, 1995

13. Gisselbrecht $C$, Lepage $E$, Molina $T$, et al: Shortened first-line high-dose chemotherapy for patients with poor-prognosis aggressive lymphoma. J Clin Oncol 20:2472-2479, 2002

14. Martelli M, Gherlinzoni F, De Renzo A, et al: Early autologous stem-cell transplantation versus conventional chemotherapy as front-line therapy in high-risk, aggressive non-Hodgkin's lymphoma: An Italian multicenter randomized trial. J Clin Oncol 21: 1255-1262, 2003 
15. Vitolo U, Liberati $A M$, Cabras MG, et al: High dose sequential chemotherapy with autologous transplantation versus dose-dense chemotherapy MegaCEOP as first line treatment in poor-prognosis diffuse large cell lymphoma: an "Intergruppo Italiano Linfomi" randomized trial. Haematologica 90:793-801, 2005

16. Simnett SJ, Stewart LA, Sweetenham J, et al: Autologous stem cell transplantation for malignancy: A systematic review of the literature. Clin Lab Haematol 22:61-72, 2000

17. Strehl J, Mey U, Glasmacher A, et al: Highdose chemotherapy followed by autologous stem cell transplantation as first-line therapy in aggressive non-Hodgkin's lymphoma: A meta-analysis. Haematologica 88:1304-1315, 2003

18. Greb A, Bohlius J, Trelle $S$, et al: High-dose chemotherapy with autologous stem cell support in firstline treatment of aggressive non-Hodgkin lymphoma results of a comprehensive meta-analysis. Cancer Treat Rev 33:338-346, 2007

19. Gianni AM, Magni M, Martelli M, et al: Long term remission in mantle cell lymphoma following high-dose sequential chemotherapy and in vivo rituximab-purged stem cell autografting (R-HDS regimen). Blood 102:749-755, 2003

20. Tarella $C$, Zanni $M$, Di Nicola $M$, et al: Prolonged survival in poor-risk diffuse large B-cell lymphoma following front-line treatment with rituximabsupplemented, early-intensified chemotherapy with multiple autologous hematopoietic stem cell support: A multicenter study by GITIL (Gruppo Italiano Terapie Innovative nei Linfomi). Leukemia 21:1802-1811, 2007

21. Vitolo U, Chiappella A, Angelucci $E$, et al: Dose-dense and high-dose chemotherapy plus rituximab with autologous stem cell transplantation for primary treatment of diffuse large B-cell lymphoma with a poor prognosis: A phase II multicenter study. Haematologica 94:1250-1258, 2009

22. Swerdlow SH, Campo E, Harris NL, et al: WHO Classification of Tumours of Haematopoietic and Lymphoid Tissues. Lyon, France, IARC Press, 2008

23. Alizadeh AA, Eisen MB, Davis RE, et al: Distinct types of diffuse large B-cell lymphoma identified by gene expression profiling. Nature 403:503-511, 2000

24. Lenz G, Wright G, Dave SS, et al: Stromal gene signatures in large-B-cell lymphomas. N Engl J Med 359:2313-2323, 2008

25. Wright G, Tan B, Rosenwald A, et al: A gene expression-based method to diagnose clinically distinct subgroups of diffuse large B cell lymphoma. Proc Natl Acad Sci USA 100:9991-9996, 2003
26. Hans $C P$, Weisenburger DD, Greiner TC, et al: Confirmation of the molecular classification of diffuse large B-cell lymphoma by immunohistochemistry using a tissue microarray. Blood 103:275-282, 2004

27. Cheson BD, Horning SJ, Coiffier $B$, et al: Report of an international workshop to standardize response criteria for non-Hodgkin's lymphomas. J Clin Oncol 17:1244, 1999

28. Cheson BD, Pfistner $B$, Juweid $M E$, et al: Revised response criteria for malignant lymphoma. J Clin Oncol 25:579-586, 2007

29. Kaplan EL, Meier P: Nonparametric estimation from incomplete observations. J Am Stat Assoc 53: 457-481, 1958

30. Müller $\mathrm{C}$, Murawski $\mathrm{N}$, Wiesen $\mathrm{MH}$, et al: The role of sex and weight on rituximab clearance and serum elimination half-life in elderly patients with DLBCL. Blood 119:3276-3284, 2012

31. Pfreundschuh $M$, Schubert J, Ziepert $M$, et al: Six versus eight cycles of bi-weekly CHOP-14 with or without rituximab in elderly patients with aggressive CD20+ B-cell lymphomas: A randomised controlled trial (RICOVER-60). Lancet Oncol 9:105-116, 2008

32. Cunningham $D$, Hawkes $E A$, Jack $A$, et al: Rituximab plus cyclophosphamide, doxorubicin, vincristine, and prednisolone in patients with newly diagnosed diffuse large B-cell non-Hodgkin lymphoma: A phase 3 comparison of dose intensification with 14-day versus 21-day cycles. Lancet 381 : 1817-1826, 2013

33. Schmitz $N$, Nickelsen $M$, Ziepert $M$, et al: Conventional chemotherapy (CHOEP-14) with rituximab or high-dose chemotherapy (MegaCHOEP) with rituximab for young, high-risk patients with aggressive B-cell lymphoma: An open-label, randomised, phase 3 trial (DSHNHL 2002-1). Lancet Oncol 13: 1250-1259, 2012

34. Récher C, Coiffier B, Haioun C, et al: Intensified chemotherapy with ACVBP plus rituximab versus standard $\mathrm{CHOP}$ plus rituximab for the treatment of diffuse large B-cell lymphoma (LNH03-2B): An open-label randomised phase 3 trial. Lancet 378 : 1858-1867, 2011

35. Molina TJ, Canioni D, Copie-Bergman C, et al: Young patients with non-germinal center B-cell-like diffuse large B-cell lymphoma benefit from in tensified chemotherapy with ACVBP plus rituximab compared with $\mathrm{CHOP}$ plus rituximab: Analysis of data from the Groupe d'Etudes des Lymphomes de l'Adulte/lymphoma study association phase III trial LNH 03-2B. J Clin Oncol 32:3996-4003, 2014
36. Batlle-López A, González de Villambrosía S, Francisco M, et al: Stratifying diffuse large B-cell lymphoma patients treated with chemoimmunotherapy: GCB/non-GCB by immunohistochemistry is still a robust and feasible marker. Oncotarget 7:18036-18040, 2016

37. Gutiérrez-García G, Cardesa-Salzmann T, Climent F, et al: Grup per l'Estudi dels Limfomes de Catalunya I Balears (GELCAB): Gene-expression profiling and not immunophenotypic algorithms predicts prognosis in patients with diffuse large B-cell lymphoma treated with immunochemotherapy. Blood 117:4836-4843, 2011

38. Roschewski M, Staudt LM, Wilson WH: Diffuse large B-cell lymphoma-treatment approaches in the molecular era. Nat Rev Clin Oncol 11:12-23, 2014

39. Scott DW, Mottok A, Ennishi D, et al: Prognostic significance of diffuse large B-cell lymphoma cell of origin determined by digital gene expression in formalin-fixed paraffin-embedded tissue biopsies. $\mathrm{J}$ Clin Oncol 33:2848-2856, 2015

40. Stiff PJ, Unger JM, Cook JR, et al: Autologous transplantation as consolidation for aggressive nonHodgkin's lymphoma. N Engl J Med 369:1681-1690, 2013

41. Vitolo U, Chiappella A, Brusamolino $E$, et al: Rituximab dose-dense chemotherapy followed by intensified high-dose chemotherapy and autologous stem cell transplantation (HDC+ASCT) significantly reduces the risk of progression compared to standard rituximab dose-dense chemotherapy as first line treatment in young patients with high-risk (aa-IPI 2-3) diffuse large b-cell lymphoma (DLBCL): Final results of phase III randomized trial DLCLO4 of the Fondazione Italiana Linfomi (FIL). ASH Annual Meeting Abstracts 120:688, 2012 (abstr 688)

42. Nowakowski GS, LaPlant B, Macon WR, et al: Lenalidomide combined with R-CHOP overcomes negative prognostic impact of non-germinal center B-cell phenotype in newly diagnosed diffuse large B-Cell lymphoma: A phase II study. J Clin Oncol 33: 251-257, 2015

43. Kenkre VP, Kahl BS: The future of B-cell lymphoma therapy: The B-cell receptor and its downstream pathways. Curr Hematol Malig Rep 7: 216-220, 2012

44. Morschhauser FA, Cartron G, Thieblemont C, et al: Obinutuzumab (GA101) monotherapy in relapsed/refractory diffuse large B-cell lymphoma or mantle-cell lymphoma: Results from the phase II GAUGUIN study. J Clin Oncol 31:2912-2919, 2013

\section{Affiliations}

Sergio Cortelazzo, Atto Billio, Andrea Piccin, and Giovanni Negri, Ospedale Centrale di Bolzano, Bolzano; Corrado Tarella and Riccardo Bruna, Azienda Ospedaliera Ordine Mauriziano and University of Turin; Marco Ladetto and Manuela Zanni, Azienda Ospedaliera Universitaria (AOU) Città della Salute e della Scienza, Turin; Alessandro Massimo Gianni, Paolo Corradini, and Massimo Di Nicola, Fondazione Istituto di Ricovero e Cura a Carattere Scientifico (IRCCS) Istituto Nazionale dei Tumori, University of Milano; Andrés J.M. Ferreri, IRCCS San Raffaele Scientific Institute; Valentina Tabanelli and Stefano Pileri, Istituto Europeo di Oncologia; Alessandro Rambaldi, University of Milano, Milan; Anna Maria Barbui, Andrea Rossi, Giuseppe Gritti, Arianna Masciulli, Federica Delaini, Cristina Boschini, and Alessandro Rambaldi, Azienda Socio Sanitaria Territoriale Papa Giovanni XXIII, Bergamo; Caterina Patti and Antonino Mulé, Azienda Ospedali Riuniti Villa Sofia-Cervello, Palermo; Valerio Zoli, Ospedale San Camillo Forlanini, Rome; Claudia Castellino, Ospedale S. Croce e Carle, Cuneo; Francesco Di Raimondo, AOU Policlinico Vittorio Emanuele University of Catania, Catania; Fabio Benedetti, University of Verona; Marco Chilosi, Azienda Ospedaliera Universitaria Integrata Verona, Verona; Giorgio La Nasa, Ospedale Binaghi, Cagliari; Guido Gini, Ospedali Riuniti, Ancona; Livio Trentin, Azienda Ospedaliera-Università di Padova, Padua; Maurizio Frezzato, Ospedale San Bortolo, Vicenza; Leonardo Flenghi, Azienda Ospedaliera di Perugia, Perugia; and Simona Falorio, Ospedale Civile Spirito Santo, Pescara, Italy. 


\section{AUTHORS' DISCLOSURES OF POTENTIAL CONFLICTS OF INTEREST}

Randomized Trial Comparing R-CHOP Versus High-Dose Sequential Chemotherapy in High-Risk Patients With Diffuse Large B-Cell Lymphomas

The following represents disclosure information provided by authors of this manuscript. All relationships are considered compensated. Relationships are self-held unless noted. I = Immediate Family Member, Inst = My Institution. Relationships may not relate to the subject matter of this manuscript. For more information about ASCO's conflict of interest policy, please refer to www.asco.org/rwc or jco.ascopubs.org/site/ifc.

\section{Sergio Cortelazzo}

No relationship to disclose

Corrado Tarella

No relationship to disclose

Alessandro Massimo Gianni

No relationship to disclose

Marco Ladetto

Honoraria: Roche, Amgen

Research Funding: Amgen, Roche

Anna Maria Barbui

No relationship to disclose

Andrea Rossi

No relationship to disclose

\section{Giuseppe Gritti}

No relationship to disclose

Paolo Corradini

Consulting or Advisory Role: Takeda Pharmaceuticals, Celgene, Amgen

Speakers' Bureau: Celgene, Takeda Pharmaceuticals, Gilead Sciences

\section{Massimo Di Nicola}

No relationship to disclose

\section{Caterina Patti}

No relationship to disclose

Antonino Mulé

No relationship to disclose

Manuela Zanni

No relationship to disclose

Valerio Zoli

No relationship to disclose

Atto Billio

No relationship to disclose

Andrea Piccin

No relationship to disclose

Giovanni Negri

No relationship to disclose

\section{Claudia Castellino}

No relationship to disclose

Francesco Di Raimondo

Speakers' Bureau: Roche

\section{Andrés J.M. Ferreri}

Consulting or Advisory Role: Gilead Sciences, Celgene, Sandoz Speakers' Bureau: Adienne, Italfarmaco

Research Funding: Celgene, Mundipharma

Fabio Benedetti

No relationship to disclose

Giorgio La Nasa

No relationship to disclose

Guido Gini

Honoraria: Pfizer, Roche, Teva Pharmaceutical Industries

Livio Trentin

No relationship to disclose

Maurizio Frezzato

No relationship to disclose

Leonardo Flenghi

Travel, Accommodations, Expenses: Roche, Takeda Pharmaceuticals, Teva Pharmaceutical Industries

Simona Falorio

No relationship to disclose

Marco Chilosi

Honoraria: Menarini Diagnostics

Riccardo Bruna

No relationship to disclose

Valentina Tabanelli

No relationship to disclose

Stefano Pileri

Honoraria: Takeda Pharmaceuticals

Consulting or Advisory Role: Takeda Pharmaceuticals

Speakers' Bureau: Takeda Pharmaceuticals

Travel, Accommodations, Expenses: Takeda Pharmaceuticals

Arianna Masciulli

No relationship to disclose

Federica Delaini

No relationship to disclose

Cristina Boschini

No relationship to disclose

Alessandro Rambaldi

Honoraria: Roche, Amgen, Pierre Fabre

Consulting or Advisory Role: Genentech, Amgen 
Appendix

\begin{tabular}{|c|c|c|c|c|c|c|c|c|}
\hline \multirow[b]{2}{*}{ Characteristic } & \multicolumn{2}{|c|}{$\begin{array}{c}\text { EFS } \\
(n=235 ; \text { events }=93)\end{array}$} & \multicolumn{2}{|c|}{$\begin{array}{c}\text { PFS } \\
(n=235 ; \text { events }=79)\end{array}$} & \multicolumn{2}{|c|}{$\begin{array}{c}\text { DFS } \\
(n=181 ; \text { events }=34)\end{array}$} & \multicolumn{2}{|c|}{$\begin{array}{c}\text { OS } \\
(n=235 ; \text { events }=65)\end{array}$} \\
\hline & HR $(95 \% \mathrm{Cl})$ & $P^{*}$ & HR $(95 \% \mathrm{Cl})$ & $P^{*}$ & HR $(95 \% \mathrm{Cl})$ & $P^{*}$ & HR $(95 \% \mathrm{Cl})$ & $P^{*}$ \\
\hline \multicolumn{9}{|l|}{ Treatment arm } \\
\hline R-CHOP & 1.00 & & 1.00 & & 1.00 & & 1.00 & \\
\hline R-HDS & 0.99 (0.66 to 1.48$)$ & .9536 & $0.78(0.50$ to 1.22$)$ & .2702 & $0.6(0.29$ to 1.21$)$ & .1501 & 0.93 (0.57 to 1.52$)$ & .7796 \\
\hline \multicolumn{9}{|l|}{ Age, years } \\
\hline$\leq 60$ & 1.00 & & 1.00 & & 1.00 & & 1.00 & \\
\hline$>60$ & 1.86 (1.07 to 3.23$)$ & .0284 & 1.93 (1.06 to 3.5$)$ & .0306 & 2.39 (0.99 to 5.77$)$ & .0535 & 1.95 (1.02 to 3.73 ) & .0437 \\
\hline \multicolumn{9}{|l|}{ Sex } \\
\hline $\mathrm{F}$ & 1.00 & & 1.00 & & 1.00 & & 1.00 & \\
\hline M & 1.15 (0.76 to 1.74$)$ & .5123 & $1.02(0.65$ to 1.6$)$ & .9198 & 0.8 (0.41 to 1.58$)$ & .5232 & 0.88 (0.54 to 1.44$)$ & .621 \\
\hline \multicolumn{9}{|c|}{ ECOG performance status } \\
\hline 0 & 1.00 & & 1.00 & & 1.00 & & 1.00 & \\
\hline 1 & $1.24(0.55$ to 2.80$)$ & .6077 & 1.70 (0.65 to 4.44$)$ & .2745 & 1.46 (0.37 to 5.86$)$ & .59 & $2.28(0.74$ to 7.01$)$ & .1485 \\
\hline 2 & 2.41 (1.19 to 4.86$)$ & .0143 & 3.28 (1.41 to 7.65$)$ & .0059 & 3.1 (0.93 to 10.35$)$ & .0662 & 3.61 (1.29 to 10.1$)$ & .0143 \\
\hline 3 & 1.6 (0.65 to 3.94$)$ & .3059 & 1.93 (0.67 to 5.58) & .2222 & 1.46 (0.29 to 7.23$)$ & .6442 & 2.76 (0.83 to 9.16$)$ & .0978 \\
\hline \multicolumn{9}{|l|}{ Ann Arbor clinical stage } \\
\hline ॥ & 1.00 & & 1.00 & & 1.00 & & 1.00 & \\
\hline III & $1.26(0.51$ to 3.15$)$ & .6144 & 1.06 (0.38 to 2.91$)$ & .9147 & 0.44 (0.1 to 1.97$)$ & .2829 & 1.03 (0.33 to 3.18$)$ & .9634 \\
\hline IV & $1.42(0.61$ to 3.26$)$ & .4146 & 1.46 (0.59 to 3.64$)$ & .4149 & $1.16(0.35$ to 3.82$)$ & .8084 & $1.53(0.55$ to 4.24$)$ & .4142 \\
\hline \multicolumn{9}{|l|}{ Bulky disease } \\
\hline No & 1.00 & & 1.00 & & 1.00 & & 1.00 & \\
\hline Yes & $0.55(0.36$ to 0.83$)$ & .0043 & $0.79(0.5$ to 1.26$)$ & .3216 & $0.52(0.27$ to 1.03$)$ & .0599 & 0.8 (0.48 to 1.35 ) & .4043 \\
\hline \multicolumn{9}{|l|}{ B symptoms* } \\
\hline No & 1.00 & & 1.00 & & 1.00 & & 1.00 & \\
\hline Yes & 1.15 (0.75 to 1.76$)$ & .5142 & 1.17 (0.74 to 1.85$)$ & .5129 & 1.31 (0.65 to 2.64$)$ & .4546 & 1.25 (0.75 to 2.08 ) & .3953 \\
\hline \multicolumn{9}{|l|}{ BM infiltration } \\
\hline No & 1.00 & & 1.00 & & 1.00 & & 1.00 & \\
\hline Yes & 0.94 (0.56 to 1.58$)$ & .8134 & 0.89 (0.51 to 1.57$)$ & .6937 & 1.61 (0.79 to 3.31$)$ & .1935 & $0.97(0.53$ to 1.79$)$ & .9253 \\
\hline \multicolumn{9}{|l|}{ No. of extranodal sites } \\
\hline $0-1$ & 1.00 & & 1.00 & & 1.00 & & 1.00 & \\
\hline$\geq 2$ & 1.34 (0.89 to 2.02$)$ & .1571 & 1.27 (0.82 to 1.98$)$ & .2881 & 1.25 (0.64 to 2.45$)$ & .516 & 1.35 (0.83 to 2.2$)$ & .2239 \\
\hline \multicolumn{9}{|c|}{ Elevated LDH (ratio to ULN) } \\
\hline$\leq 1$ & 1.00 & & 1.00 & & 1.00 & & 1.00 & \\
\hline$>1 \leq 3$ & 0.83 (0.47 to 1.46$)$ & .5217 & 0.88 (0.47 to 1.66$)$ & .6897 & $0.61(0.25$ to 1.45$)$ & .2616 & 0.95 (0.46 to 1.97$)$ & .8910 \\
\hline$>3$ & 1.24 (0.63 to 2.44$)$ & .5318 & 1.69 (0.82 to 3.49 ) & .1528 & 1.57 (0.58 to 4.21$)$ & .3736 & 2.17 (0.97 to 4.83$)$ & .0584 \\
\hline \multicolumn{9}{|l|}{ IPI } \\
\hline Intermediate-high & 1.00 & & 1.00 & & 1.00 & & 1.00 & \\
\hline High & 1.78 (1.18 to 2.67$)$ & .0058 & 2.08 (1.33 to 3.25$)$ & .0013 & $1.63(0.83$ to 3.21$)$ & .1536 & 2.17 (1.32 to 3.55$)$ & .0022 \\
\hline \multicolumn{9}{|l|}{ NCCN IPI } \\
\hline$\leq 3$ & 1.00 & & 1.00 & & 1.00 & & 1.00 & \\
\hline$>3$ & 1.81 (1.14 to 2.87$)$ & .0112 & $1.82(1.1$ to 3.00$)$ & .0190 & $1.67(0.80$ to 3.50$)$ & .1712 & 1.58 (0.92 to 2.69$)$ & .0960 \\
\hline \multicolumn{9}{|l|}{ Cell of origin } \\
\hline GCB & 1.00 & & 1.00 & & 1.00 & & 1.00 & \\
\hline Non-GCB & 0.90 (0.56 to 1.45$)$ & .6638 & $0.75(0.45$ to 1.26$)$ & .2848 & 0.72 (0.33 to 1.58$)$ & .4100 & 0.77 (0.43 to 1.36$)$ & .3692 \\
\hline PML & $0.54(0.24$ to 1.24$)$ & .1458 & 0.62 (0.27 to 1.43$)$ & .2629 & $0.41(0.09$ to 1.86$)$ & .2485 & $0.76(0.32$ to 1.80$)$ & .5304 \\
\hline NE & 1.01 (0.53 to 1.92$)$ & .9715 & 1.02 (0.52 to 1.99$)$ & .9621 & 1.13 (0.44 to 2.92$)$ & .7996 & 0.94 (0.44 to 2.01$)$ & .8699 \\
\hline $\begin{array}{l}\text { Abbreviations: BM, bo } \\
\text { Index; LDH, lactate deh } \\
\text { survival; PML, primary } \\
\text { sequential chemothera } \\
\text { * Result of Wald test }\end{array}$ & $\begin{array}{l}\text { DFS, disease-free s } \\
\text {; NCCN, National Co } \\
\text { lymphoma; R-CHOF } \\
\text { pper limit of normal. } \\
\text { te Cox model. }\end{array}$ & $\begin{array}{l}\text { jival; E } \\
\text { prehen } \\
\text { jituxim }\end{array}$ & $\begin{array}{l}\text { event-free survival } \\
\text { Cancer Network; } \\
\text { lus cyclophosphan }\end{array}$ & $\begin{array}{l}\mathrm{CB} \text {, ger } \\
\text { not ev }\end{array}$ & $\begin{array}{l}\text { al center B-cell-like; } \\
\text { ble for lack of materi } \\
\text { cin, vincristine, and p }\end{array}$ & $\begin{array}{l}\text { nazar } \\
\text { S, ov } \\
\text { isone }\end{array}$ & $\begin{array}{l}\text { io; IPI, International } \\
\text { survival; PFS, progr } \\
\text { HDS, rituximab plus }\end{array}$ & $\begin{array}{l}\text { ognostic } \\
\text { sion-free } \\
\text { gh-dose }\end{array}$ \\
\hline
\end{tabular}


Randomized Trial of R-CHOP Versus R-HDS in High-Risk DLBCL

\begin{tabular}{|c|c|c|c|c|c|c|c|c|}
\hline \multirow[b]{2}{*}{ Characteristic } & \multicolumn{2}{|c|}{ 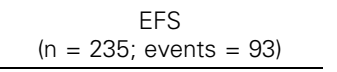 } & \multicolumn{2}{|c|}{$\begin{array}{c}\text { PFS } \\
(n=235 ; \text { events }=79)\end{array}$} & \multicolumn{2}{|c|}{ 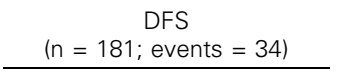 } & \multicolumn{2}{|c|}{$\begin{array}{c}\text { OS } \\
(n=235 ; \\
\text { events }=65)\end{array}$} \\
\hline & $\operatorname{HR}(95 \% \mathrm{Cl})$ & $P$ & $\mathrm{HR}(95 \% \mathrm{Cl})$ & $P$ & $\mathrm{HR}(95 \% \mathrm{Cl})$ & $P$ & $\operatorname{HR}(95 \% \mathrm{Cl})$ & $P$ \\
\hline \multicolumn{9}{|l|}{ Treatment arm } \\
\hline $\mathrm{R}-\mathrm{CHOP}$ & 1.00 & & 1.00 & & 1.00 & & 1.00 & \\
\hline R-HDS & 1.05 (0.7 to 1.6$)$ & .8011 & $0.84(0.53$ to 1.32$)$ & .4464 & $0.58(0.29$ to 1.2$)$ & .142 & 1 (0.61 to 1.64$)$ & .9946 \\
\hline \multicolumn{9}{|l|}{ Sex } \\
\hline $\mathrm{F}$ & 1.00 & & 1.00 & & 1.00 & & 1.00 & \\
\hline $\mathrm{M}$ & $1.16(0.76$ to 1.76$)$ & .4965 & $1.01(0.64$ to 1.59$)$ & .974 & $0.84(0.42$ to 1.68$)$ & .6153 & $0.9(0.55$ to 1.48$)$ & .6785 \\
\hline \multicolumn{9}{|l|}{ Age } \\
\hline$\leq 60$ & 1.00 & & 1.00 & & 1.00 & & 1.00 & \\
\hline$>60$ & 1.66 (0.92 to 2.98$)$ & .0905 & $1.7(0.91$ to 3.18$)$ & .0973 & 2.01 (0.8 to 5.05$)$ & .1371 & 1.74 (0.88 to 3.43 ) & .1097 \\
\hline \multicolumn{9}{|l|}{ BM infiltration } \\
\hline No & 1.00 & & 1.00 & & 1.00 & & 1.00 & \\
\hline Yes & 0.84 (0.5 to 1.43$)$ & .5232 & $0.81(0.45$ to 1.43$)$ & .4599 & 1.47 (0.7 to 3.08 ) & .3037 & $0.87(0.47$ to 1.62$)$ & .6646 \\
\hline \multicolumn{9}{|l|}{ B symptoms } \\
\hline No & 1.00 & & 1.00 & & 1.00 & & 1.00 & \\
\hline Yes & 1.09 (0.7 to 1.69$)$ & .7004 & 1.09 (0.68 to 1.76$)$ & .7093 & 1.3 (0.63 to 2.68$)$ & .4824 & 1.2 (0.71 to 2.03 ) & .4899 \\
\hline \multicolumn{9}{|l|}{$\mid \mathrm{PI}$} \\
\hline Intermediate-high & 1.00 & & 1.00 & & 1.00 & & 1.00 & \\
\hline High & 1.7 (1.11 to 2.62$)$ & .0149 & 1.95 (1.23 to 3.11$)$ & .0049 & $1.48(0.73$ to 3$)$ & .2818 & 1.99 (1.19 to 3.33 ) & .0084 \\
\hline \multicolumn{9}{|l|}{ Cell of origin } \\
\hline GCB & 1.00 & & 1.00 & & 1.00 & & 1.00 & \\
\hline Non-GCB & 0.82 (0.5 to 1.33 ) & .4175 & 0.7 (0.41 to 1.18 ) & .1839 & $0.71(0.32$ to 1.58$)$ & .4029 & 0.7 (0.39 to 1.25$)$ & .2304 \\
\hline PML & $0.53(0.23$ to 1.22$)$ & .1365 & $0.6(0.26$ to 1.39$)$ & .2326 & 0.39 (0.09 to 1.8$)$ & .2304 & 0.74 (0.31 to 1.76$)$ & .4898 \\
\hline $\mathrm{NE}$ & 0.97 (0.5 to 1.89$)$ & .9327 & 0.99 (0.5 to 1.98$)$ & .9809 & $1.03(0.38$ to 2.76$)$ & .953 & $0.88(0.41$ to 1.92$)$ & .7563 \\
\hline
\end{tabular}




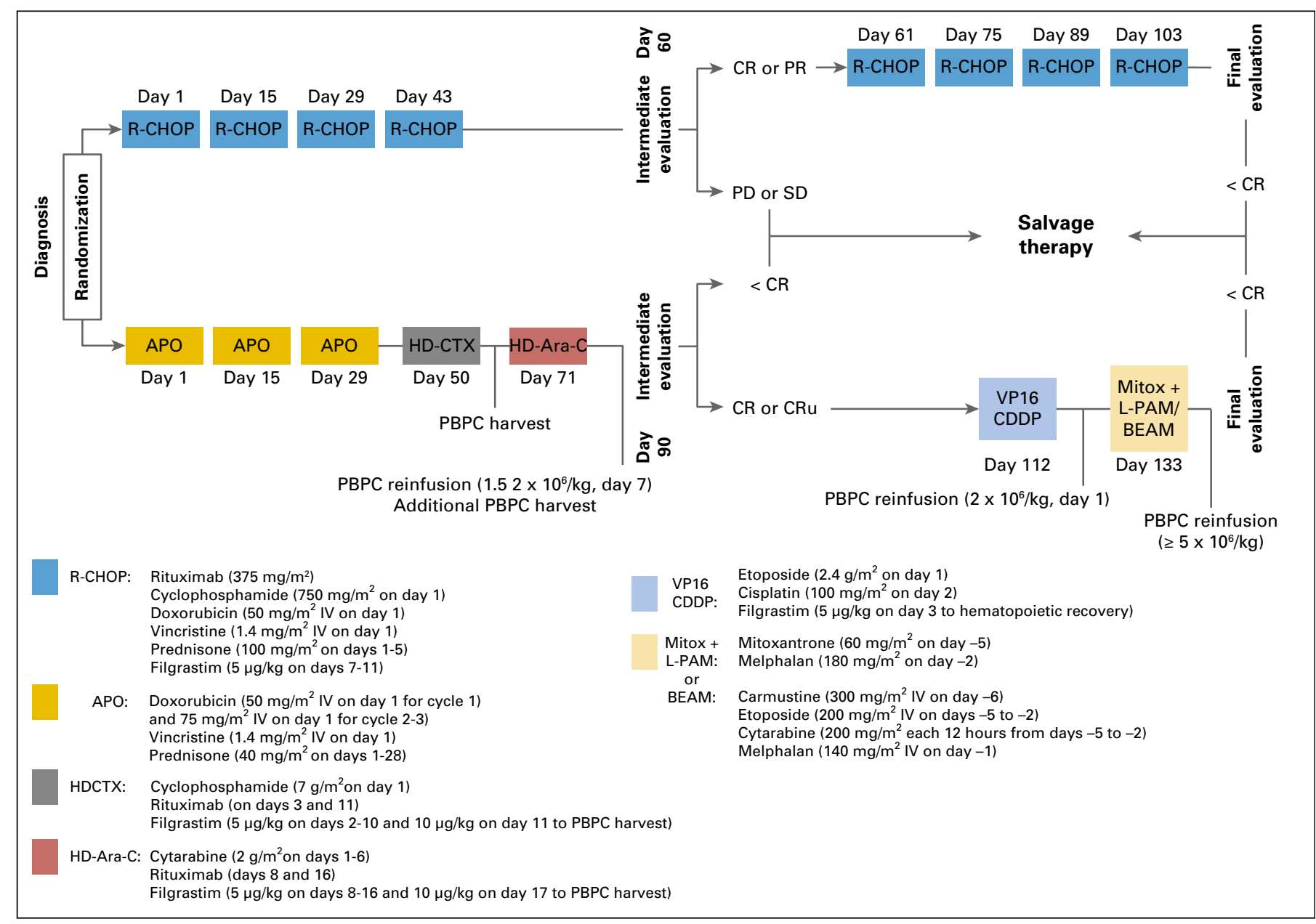

Fig A1. Study design. APO, doxorubicin $50 \mathrm{mg} / \mathrm{m}^{2} \mathrm{IV}$ followed by the full dose of $75 \mathrm{mg} / \mathrm{m}^{2} \mathrm{IV}$ at 14 and 28 days, vincristine $1.4 \mathrm{mg} / \mathrm{m}^{2} \mathrm{IV}$ on days 1,14 , and 28 , and oral prednisone $40 \mathrm{mg} / \mathrm{m}^{2}$ on days 1 to 28; BEAM, carmustine, etoposide, cytarabine, melphalan; CDDP, cisplatin; CR, complete response; CRu, complete response unconfirmed; HD-Ara-C, high-dose cytarabine; HD-CTX, high-dose cyclophosphamide; IV, intravenously; L-PAM, melphalan; mitox, mitoxantrone; PBPC, peripheral blood progenitor cells; PD, progressive disease; PR, partial response; R-CHOP, rituximab plus cyclophosphamide, doxorubicin, vincristine, and prednisone; SD, stable disease; VP16, etoposide. 


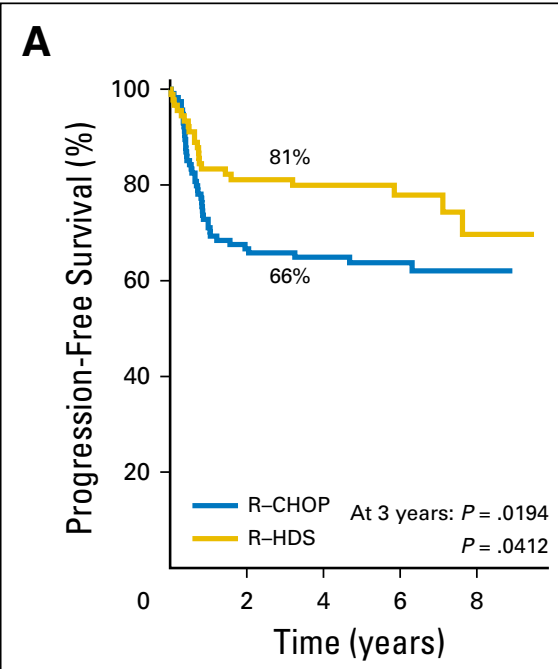

No. at risk

$\begin{array}{rrrrrr}\text { R-CHOP } & 115 & 76 & 67 & 42 & 12 \\ \text { R-HDS } & 90 & 72 & 61 & 35 & 10\end{array}$

B

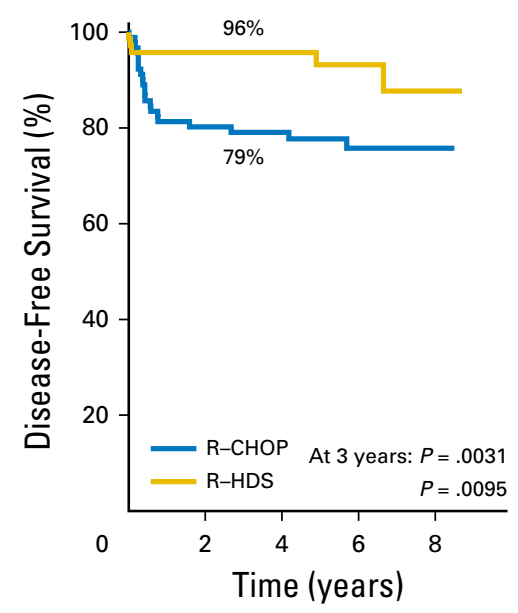

No. at risk

$\begin{array}{llllll}\text { R-CHOP } & 91 & 73 & 61 & 34 & 7\end{array}$
C

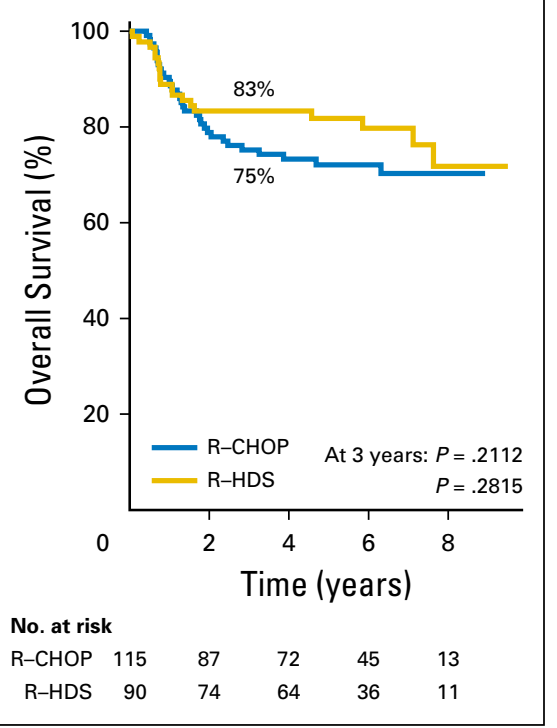

Fig A2. (A) Progression-free survival, (B) disease-free survival, and (C) overall survival of patients not discontinuing the allocated treatment because of toxicities (medical

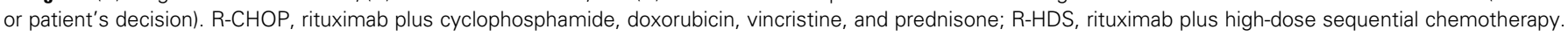

